Tuva Bjørkvold er førsteamanuensis ved OsloMet - storbyuniversitetet, Institutt for grunnskole- og

faglærerutdanning. Hennes forskningsinteresser er utforskende arbeidsmåter, elever som forskere,

naturfaglig literacy og skriving som grunnleggende ferdighet.

TUVA BJØRKVOLD

OsloMet - storbyuniversitetet, Fakultet for lærerutdanning og internasjonale studier,

Institutt for grunnskole- og faglærerutdanning, Norge

Tuva.bjorkvold@oslomet.no

\title{
Arbeidstekster i utforskende arbeidsmetoder
}

\begin{abstract}
Inquiry learning depends on a variety of writing in order to plan, collect data and keep track of the information. In school science, however, writing to document teacher initiated experiments, following a setup, is widespread. This article follows a class of students during inquiry learning. Most of the student texts are so called working texts, texts used to gather and process their data. Thus, the students writing practice is closer to that of scientists, as opposed to the praxis characterizing scientific literacy in school, as reproducing and concerning the schooled text culture, such as textbooks. This article argues that the term working texts can pose a useful contribution to the view of writing in school science.
\end{abstract}

\section{INNLEDNING}

Skriving er essensielt i naturfag, både for å planlegge, samle, systematisere, få oversikt og formidle kunnskap (Cetina \& Reichmann, 2015; Norris \& Phillips, 2003; Osborne, 2007; Sørvik \& Mork, 2015). Uten tekst ville ikke naturfaget ha sin berettigede plass, for det er teksten som gjør at kunnskapen kan lagres, formidles på tvers av tid og rom, og danne grunnlag for ny kunnskap (Lemke, 1990; Yore et al., 2004). Det er stor enighet om at det kreves mye skriving for å komme til en ferdig publikasjon, men situasjonen i skolen er en ganske annen. Naturfaglig skriving i skolen er i stor grad reproduserende, i motsetning til konstruksjonen som foregår i vitenskapsfagene (Danielsson, 2010; Osborne, 2007; Sørvik \& Mork, 2015). Elevenes skriving domineres av rapporter fra forsøk initiert av læreren, og som fragmenterte svar på spørsmål i lærebøker (Lyons, 2006).

Om elevene skal få en større innsikt i hva naturfaget innebærer, også når det gjelder å konstruere kunnskap, trenger de erfaring med skriving i flere faser av kunnskapstilegnelsen. Dermed kan også den sosiale siden ved skrivingen bedre framheves (Klein \& Boscolo, 2016), som del av utforskende arbeid. Denne artikkelen studerer en klasse på barnetrinnet som jobber utforskende, gjennom å teste ut egne hypoteser til en selvvalgt problemstilling. Elevene skriver en mengde tekster underveis i arbeidet, men bare et fåtall av dem havner i den endelige rapporten. Det kan derfor være interessant å ta tak i hva som kjennetegner elevenes skriving i hele utforskningsforløpet gjennom problemstillingen:

Hvilke formål har tekstene elevene skriver når de jobber utforskende? Og hvilke implikasjoner kan elevenes skrivepraksis ha for utforskende arbeid i skolen? 
For å nærme meg denne problemstillingen presenterer jeg først teori og tidligere forskning om forholdet mellom naturfag og tekst, særlig skriving, i forskning og skole. Deretter ser jeg på hva som karakteriserer utforskende arbeidsmåter. Videre presenterer jeg studien, en informasjonsorientert kasusstudie som gjennom en metodetriangulering av elevtekster, videoobservasjoner og elevintervjuer setter fokus på hva elevene bruker tekstene de skriver til. Klassen i studien jobber innen tradisjonen åpen utforsking, der elevene selv velger problemstilling og metode.

\section{TEORI OG TIDLIGERE FORSKNING OM SKRIVING OG NATURFAG I FORSKNING OG SKOLE}

Naturfag og tekst er gjensidig avhengig av hverandre, og inngår i et sosialt system skapt av dem som skriver og leser innen faget (Knain, 2015). Dette samspillet, der en bruker tekst hensiktsmessig i ulike situasjoner, kalles literacy (Barton, 2007). Literacy innebærer å skape mening med tekst, både gjennom å skrive, lese og samtale om tekst. Innen naturfaget peker Steven P. Norris og Linda M. Philips (2003) på to aspekter innen naturfaglig literacy. Den første er den fundamentale (fundamental) forståelsen av literacy, som omhandler å beherske språket, kommunikasjonssystemer og måter å formulere seg på. Den andre er den avledede (derived) forståelsen av literacy, som omhandler å ha kunnskap og kjenne til fakta fra naturfaget. Om skolen fokuserer bare på den avledede kunnskapen, vil elevene miste en viktig dimensjon av naturfaget, nemlig den som omhandler å skape kunnskap og å delta i det naturfaglige fellesskapet (Sørvik, Blikstad-Balas, \& Ødegaard, 2015). Dermed er det av betydning på hvilken måte elevene møter naturfagets literacy i skolen. Om vi ønsker at elevene skal få erfaring med både den fundamentale og den avledede forståelsen av literacy, må de derfor få anledning til å møte situasjoner både der de selv skal skape kunnskap gjennom utforsking, og der de tilegner seg etablert kunnskap.

Jonathan Osborne (2007) argumenterer for at elever må få anledning til å utvikle evnen til kritisk tenkning angående naturfaglige spørsmål. Da må elevene møte data som ikke gir tydelige konklusjoner, og få mulighet til å overveie og teste ut ulike tilnærminger (ibid.) Dette krever tid og en forståelse for at det er verd å bruke tid. Å bale med uhåndterlige data blir gjerne gjort gjennom tekst. Dette framhever Steve Graham og Dolores Perin i innledningen av den store metaundersøkelsen Writing Next:

If students are to make knowledge their own, they must struggle with the details, wrestle with the facts, and rework raw information and dimly understood concepts into language they can communicate to someone else. In short, if students are to learn, they must write (Graham \& Perin, 2007, s. 9).

Som påpekt ser skolens literacy generelt, og i naturfag spesielt, ut til å være dominert av reproduksjon, fragmentert skriving og hyppig bruk av lærebøker (Sørvik \& Mork, 2015). Et alternativ ser vi i det norske prosjektet Forskerføtter og leserøtter (Ødegaard, Haug, Mork, \& Sørvik, 2014) som bygger på det amerikanske Seeds of Sciense, Roots of Reading (Cervetti, Barber, Dorph, Pearson, \& Goldschmidt, 2012). Her integreres utforskende læring i naturfag og literacy. Prosjektet videreutdannet lærere i barneskolen, for så å studere når disse gjennomfører spesifikke naturfagsøkter der utforsking, diskusjon, lesing og skriving er med. Elevenes literacypraksiser er undersøkt. I dette arbeidet er elevenes skriftlige arbeid i stor grad styrt av læreren, blant annet med tanke på hvilke begreper de skal lære. Men det kommer fram at elevene skriver en del også underveis i arbeidet, og at de kopler inn erfaringer hentet utenfra skolekonteksten (Sørvik et al., 2015).

Også i aksjonsforskningsprosjektet ElevForsk, som har studert elever i ulike utforskende aktiviteter, framheves en tett kopling mellom faglighet og skriftlighet. Prosjektet bygger på en tese om at utforskende arbeidsmåter og de grunnleggende ferdighetene «i praksis konstituerer hverandre» (Kolstø \& Knain, 2011, s. 51), noe jeg forstår som at de er gjensidig avhengige av hverandre. Funnene peker på tekst som forutsetning, middel og mål for læringen. 
Multimodalitet, der tekst kombineres med bilder, illustrasjoner, grafer og andre uttrykksformer, er normaliteten i naturfaget (Lemke, 1990). Kristina Danielsson (2013), fra Sverige, har derfor studert multimodalitet i naturfaglige tekster i skolen, både de elever skriver og i tekster elevene leser. Hun finner blant annet at elevene stort sett skriver av det læreren skriver på tavla, ikke egne observasjoner eller tanker. I tillegg får de ikke med seg det læreren sier eller understreker med gester. Den multimodale framstillingen forsvinner dermed i elevenes skriftlige reproduksjon.

\section{Skriving som sosialt situert}

For å kunne studere hvordan elevene skriver, tar jeg utgangpunkt i at literacy er sosial praksis som involverer tekst, sentralt i perspektivet New Literacy Studies (Barton, 2007; Gee, 2015b). Literacy er noe en gjør, i spesielle situasjoner, og ikke en ferdighet en besitter. Elevenes skriving i skolen må derfor studeres i den sammenhenger den finner sted, og bli analysert med dette utgangpunktet (Gee, 2015a). De konkrete, observerbare situasjonen der tekst brukes, kalles literacyhendelser (Street \& Hornberger, 2008). Jeg studerer situasjoner der skriving spiller en rolle, skrivehendelser (Rish, 2015). Ved å studere mange liknende hendelser kan en utlede en literacy- eller skrivepraksis (Barton \& Hamilton, 2000). Forholdet kan beskrives som forholdet mellom vær og klima (Knain, 2015): Været kan du observere fra dag til dag, ved for eksempel å registrere nedbør og temperatur. På bakgrunn av disse observasjonene kan du etter en tid utlede klimaet for dette stedet. Dermed kan en på bakgrunn av observasjoner av mange liknende skrivehendelser tolke seg fram til skrivepraksisene i en spesiell situasjon.

\section{Utforskende arbeidsmåter}

$\AA$ jobbe utforskende kan plasseres innen den fundamentale forståelsen av naturfaglig literacy, det handler om å skape mening av noe en erfarer og sette ord på det (Abd-El-Khalick et al., 2004; Norris \& Phillips, 2003). Utforskende arbeidsmåter handle om å nærme seg det vitenskapsfolk gjør, «doing what scientists do» (Howes, Lim, \& Campos, 2009, s. 190). Stein Dankert Kolstø og Erik Knain (2011) trekker fram tre kjennetegn på utforskende arbeidsmåter. For det første starter arbeidet med et spørsmål, en problemstilling. For det andre oppfordres elever til å danne egne hypoteser eller forsøksvise svar. For det tredje brukes innsamlet data eller annen informasjon som grunnlag for å nærme seg et svar. En kan tenke seg en rekke av utforskende arbeidsmåter, varierende for eksempel med tanke på hvilken rolle læreren og eleven har når det gjelder valg av problemstilling, hypoteser, metode og presentasjonsform (Herron, 1971). I noen tilfeller brukes også termen utforskende arbeidsmetode der resultatet er gitt, men veien fram er mer åpen for elevene (Kolstø \& Knain, 2011).

Studien i denne artikkelen er basert på en utforskende arbeidsmåte der elevene velger problemstilling, hypoteser og metode. Resultatet er ikke gitt på forhånd, men avhenger av elevenes utforsking. Elevene bruker en forenklet variant av hypotetisk-deduktiv metode (Furøy, Møllhausen, \& Hauge, 2014). Denne tilnærmingen kan karakteriseres som åpen utforsking (Kolstø \& Knain, 2011, s. 29), men med en fast struktur. Det innebærer at elevene veiledes i å finne problemstilling og teste ut egne hypoteser til denne systematisk. Det er høy grad av frihet, eller såkalte frihetsgrader, da både problem og metodisk tilnærming, innenfor en hypotesetestende kultur, blir bestemt av elevene (Herron, 1971). Videre er formidling av forskningen sentralt. Enkelte hevder at forskningen først er fullbyrdet nettopp når den er formidlet (Harzing, 2011). For voksne forskere er dette normen, men at elever formidler til utenforstående, hører med til unntakene (Mills et. al, 2014). Denne store grad av frihet og krav om formidling til ukjente mottakere, gjør at praksisen til disse elevene kan fortone seg uvanlig fri og krevende. Samtidig kan dette utgangpunktet gi rom for praksiser som kan implementeres i utforskende arbeidsmåter med også lavere grad av sakskompleksitet og lavere antall frihetsgrader, i ulike varianter av veiledet utforsking. 


\section{METODE}

\section{Kontekst for studien}

Studien er gjort i Norge, der barneskolen er fra 1. - 7. trinn, med elever fra 6 - 13 år. Det er en forskriftsfestet nasjonal læreplan, Kunnskapsløftet (Kunnskapsdepartementet, 2019), med kompetansemål for hovedtrinn i skolen 1. - 4. og 5. - 7. I lokale læreplaner på skolene settes mål for trinn, med årsplaner og områder som særlig blir satset på. I fagene naturfag og samfunnsfag er utforskende arbeidsmåter nasjonalt både et hovedområde i faget, og en tilnærming som skal brukes i faget gjennom hele skoleløpet i grunnskolen og på videregående skole. I ny overordnet del for skolen vektlegges det at elever i alle fag skal arbeide med vitenskapelig tilnærming til fag og kritisk tenkning (Udir, 2018). Utforskende arbeidsmåter er dermed tydelig framhevet i læreplanen.

Studien er en strategisk valgt kasus (Flyvbjerg, 2010) av elever som jobber utforskende ved å delta i Nysgjerrigper. Nysgjerrigper er en forskningskonkurranse for barnetrinnet arrangert av Forskningsrådet i Norge (Nysgjerrigper, 2019). Skoler kan velge å delta, for blant annet å oppfylle kravene til utforsking i læreplanen. De fleste deltar i Nysgjerrigper gjennom skolen, og jobber tverrfaglig med særlig naturfag, norsk og matematikk for å gjennomføre sitt egenvalgte forskningsprosjekt. Elevene skal selv finne problemstilling, formulere hypoteser, teste ut disse systematisk og presentere resultatene i en skriftlig rapport. Nysgjerrigper, og dermed elevene, kaller tilnærmingen å forske, og det vil jeg også anvende for stilistisk variasjon. Konkurransen har vært relativt uendret siden 1990, og opp mot 3000 elever deltar årlig (Nysgjerrigper, 2018). Konkurransen kårer vinnere, og kravene tilpasses skoletrinnet, noe som gjør at elever fra 1. - 7. klasse har like muligheter til å vinne, på egne premisser. Kriteriene for å nå langt i konkurransen handler om å vise en god tilnærming til problemstillingen sin, at metodene egner seg til å teste hypotesene, at resultatene blir tolket i lys av hypotesetestingen og at det tydelig er elevenes stemme som formidler alle sider ved forskningsprosessen. I tillegg får alle som deltar en skriftlig tilbakemelding på sin rapport.

\section{Utvalg}

En kasusstudie kjennetegnes ved et bevisst utvalg (Stake, 2005), her elever som jobber utforskende. Avgrensningen var i dette tilfellet naturlig. Jeg fulgte en klasse som deltok i Nysgjerrigper fra de begynte å tenke på problemstilling til de hadde skrevet en ferdig forskningsrapport, om lag åtte uker. Klassen som studeres, består av 6 jenter og 15 gutter på 7. trinn. På skolen er åpen utforsking en del av den lokale læreplanen, og har vært det i en årrekke. Elevene har således jobbet med utforskende arbeidsmåter generelt, og Nysgjerrigper spesielt, i seks år tidligere og har god kompetanse i arbeidsmåten. Utforskende holdning til fag og å stille kritiske spørsmål er dermed en del av klasse- og skolekulturen. Klassen omtales som krevende, men med høy læringslyst i motiverende situasjoner. De presterer gjennomsnittlig på nasjonale og kommunale kartleggingsprøver. Læreren er særlig erfaren i metoden, og er veileder på skole-, kommune- og nasjonalt nivå innen arbeidsformen.

Elevene i studien forsket i fellesskap på den egenvalgte problemstillingen: Hvor langt unna kan hunder lukte en godbit? De testet ut hypoteser om størrelsen på nesa avgjorde, om hundens farge spilte noen rolle, og om jakthunder var dyktigere enn andre hunder. Blant annet gjorde de systematiske hundeeksperimenter, intervjuet eksperter og søkte i relevant litteratur. Elevene organiserte seg i grupper som jobbet med ulike metoder og bidro alle med tekster til det endelige produktet. Arbeidet endte i en skriftlig rapport på 54 A4-sider, som elevene selv redigerte og sendte inn til konkurransen. Elevene kom ikke til finalen i konkurransen.

Prosjektet varte i åtte uker, 26 timer totalt, der det normalt ble arbeidet 1-2 timer daglig. Læreren fungerte som faglig veileder og praktisk tilrettelegger, men overlot til elevene å ta faglige avgjørelser, skrive tekster på alle nivåer, utføre eksperimenter og samle data på andre måter. Læreren oppfordret ikke elevene eksplisitt til å skrive i ulike teksttyper. Hun ga heller ikke elevene opplæring i skriving i perioden som er studert. Hvilken skriveopplæring elevene hadde fătt før prosjektperioden, er ikke kjent for forfatteren og var heller ikke etterspurt. En analyse av datamaterialet, angående hvem som initierte skrivingen, viser at læreren kun i $14 \%$ av skrivehendelsene instruerte elevene til å skrive 
(Bjørkvold \& Blikstad-Balas, 2017). I de resterende $86 \%$ av tilfellene valgte elevene selv å løse utfordringer gjennom skriving. Tekstkategoriene som presenteres i artikkelen var ikke kjent verken for læreren eller elevene i prosjektperioden.

\section{Datainnsamling}

For å studere hva som karakteriserer tekstene når elevene jobber utforskende, har jeg benyttet en metodetriangulering rundt elevenes skrivehendelser (Cohen, Bell, Manion, \& Morrison, 2011). For det første har jeg samlet inn alle elevtekster som er produsert i perioden, både håndskrevne og digitale. Jeg karakteriserer en tekst som et produkt med skrift eller andre meningsbærende semiotiske ressurser, som tegning, foto eller symboler, som skaper en mening. Tekstene er daglig enten scannet direkte i klasserommet, eller kopiert fra skolens server. Ingen elever nektet meg å skanne tekstene deres, men de var informert om at de kunne velge dette.

For det andre har jeg gjort videoobservasjon gjennom et fastmontert kamera som fanget opp hele klasserommet, med trådløs mikrofon på læreren. Dette er gjort for å få et overordet blikk på sammenhengen elevene skriver i. Dette kan demme opp noe for en forstørring av små hendelser, en svakhet ved noen videostudier (Blikstad-Balas, 2016). Videre har jeg plassert hodekamera med innebygget mikrofon på tre elever. For å få et best mulig innblikk i hva som karakteriserte elevenes skrivehendelser samlet sett, var det bare ett kamera i hver elevgruppe. Én elev hadde kamera gjennom én dag, for å sikre kontinuitet i pågående skrivearbeider. I tillegg ønsket jeg noen ganger å følge en spesiell tekst eller variere hvem som hadde kamera. Totalt ønsket 19 av 21 elever å ha kamera på hodet, og alle fikk mulighet i løpet av de åtte ukene prosjektet deres varte.

For det tredje har jeg gjennomført videostimulerte intervjuer med elever. Mens elevene arbeidet utforskende, noterte jeg som ikke-deltakende observatør (Gall, Gall \& Borg, 2007), tidspunkt for når skrivehendelser startet, enten ved at elevene skrev for hånd eller på skjerm. I elevenes friminutt fant jeg aktuelle klipp, fra minnebrikken i elevenes hodekamera, der elevene startet å skrive, og vurderte om dette var aktuelt for intervju. Når elevene kom tilbake til timen, spurte jeg om de ville bli intervjuet. Ingen reserverte seg. På et grupperom viste jeg filmklippet på en datamaskin, der elevene selv fikk starte og pause videoen. Jeg ba elevene fortelle med egne ord hva de gjorde på klippet, hva de skrev og hvorfor. Jeg hadde en intervjuguide, så intervjuene var semistrukturerte (Kvale \& Brinkmann, 2009), med vektlegging av formål med skriving. Totalt gikk det ikke mer enn 60 minutter fra elevene hadde skrevet til de ble intervjuet. Tabell 1 viser en oversikt over det samlede datamaterialet.

Tabell 1 Oversikt over datamateriale

\begin{tabular}{|l|l|}
\hline Datamateriale & Antall totalt \\
\hline Elevtekster & 344 totalt \\
\hline Videoobservasjon & 26 timer over åtte uker \\
& -1 klassekamera -26 timer \\
& -3 hodekameraer -78 timer \\
\hline Elevintervjuer & 22 intervjuer, ca. 150 min \\
\hline
\end{tabular}

\section{Analyse}

Jeg startet analysen med å finne alle oppstarter av skrivehendelser, gjennom åpen koding (Cohen et al., 2011). Deretter så jeg, ved hjelp av selektiv koding, på hva som karakteriserte oppstarten av elevenes skriving (Creswell, 1998). Da kunne jeg lete etter mønstre i ulike formål for skriving. På bakgrunn av elevenes skrivehendelser og elevintervjuer, kunne jeg danne meg en forståelse av deres skrivepraksiser, med tanke på hva de brukte tekstene til. 
Analyseapparatet er en kategorisering av formål med skriving i den gitte konteksten. Tekstene, eller rettere sagt skrivehendelsene, er kodet i tre gjensidig utelukkende kategorier (Tabell 2): Tenketekster, arbeidstekster og presentasjonstekster. Kategoriene som ble brukt (Bjørkvold, 2013, Bjørkvold \& Blikstad-Balas, 2017) tar utgangpunkt i Hoel (1997). Tenketekster er tekster som er skrevet primært for å klargjøre egne tanker. Eksempler på disse er tankekart og skisser. Arbeidstekster er skrevet primært for å skaffe eller håndtere informasjon. Typiske eksempler er notater gjort under eksperimenter eller lesing av faglitteratur, e-poster og brev skrevet til eksperter, og strukturerende tekster til datainnsamling- og håndtering som tabeller. Presentasjonstekster er skrevet primært for å presentere informasjon, særlig for mottakere utenfor skrivesituasjonen. Noen eksempler er artikler, tabeller med resultater, rapporter og tekster som rammer inn rapporter, som forside, forord, innholdsfortegnelse og liste over kilder.

Tabell 2 Oversikt over kategorier for formål med skriving

\begin{tabular}{|l|l|l|}
\hline Kategori & Beskrivelse & Eksempel \\
\hline Tenketekst & $\begin{array}{l}\text { Skrevet primært for å klargjøre egne tanker, alene } \\
\text { eller i gruppe. }\end{array}$ & Tankekart, skisser \\
\hline Arbeidstekst & $\begin{array}{l}\text { Skrevet primært for å skaffe og håndtere infor- } \\
\text { masjon. Tekstene kan være rettet mot noen uten- } \\
\text { for eller innenfor klasserommet, men mot andre } \\
\text { enn den som skrev teksten. }\end{array}$ & Notater, e-poster, brev \\
\hline $\begin{array}{l}\text { Presentasjons- } \\
\text { tekst }\end{array}$ & Skrevet primært for å presentere informasjon. & $\begin{array}{l}\text { Artikler, tabeller med } \\
\text { resultater, rapporter }\end{array}$ \\
\hline
\end{tabular}

Det er viktig å presisere at termene tenketekst, arbeidstekst og presentasjonstekst inkluderer skrivehendelsen, ikke bare teksten. Termene framhever det primære bruksformålet tekstene hadde i den konkrete skrivehendelsen, for elevene. Andre formål kan også ha forekommet, men det primære framheves her. Videre må det understrekes at all skriving inkluderer tenking. Kategorien tenketekst kjennetegnes særlig ved at den er skrevet for å klargjøre tanker, innad i en gruppe eller for en person. Dermed skiller den seg fra arbeidstekster som kan være rettet mot andre, og der funksjonen særlig er å skaffe og håndtere informasjon, ikke å få klarhet i egne tanker.

\section{Validitet og reliabilitet}

I en kasusstudie henger reliabilitet i stor grad sammen med å ha et transparent design og analyse (Hammersley, 2008). Metodetriangulering øker også validiteten til kvalitative studier (Creswell \& Miller, 2010). I videostudier må en særlig være oppmerksom på kameraeffekter, ved såkalt forstørring av hendelser (Blikstad-Balas, 2016) og unaturlig oppførsel, som bryter med vanlig praksis (Lauriel \& Philo, 2012). For å demme opp mot dette, og min tilstedeværelse som ikke-deltakende observatør og intervjuer, var jeg med alt utstyret i klasserommet for å venne elever og lærer til min tilstedeværelse, en såkalt habituering (Haw \& Hadfield, 2011). Det ble ikke observert avvikende eller unaturlig oppførsel i perioden for datainnsamling og habituering.

\section{RESULTATER}

Totalt skrev elevene 344 tekster, ikke medregnet ca. 120 problemstillinger. Fordelingen er kvantifisert for å gi en indikasjon om trender, men datagrunnlaget er ikke stort nok til å kunne generalisere fra disse funnene. Tenketekstene utgjør $18 \%$ at materialet. Arbeidstekstene er den klart største gruppen av tekster, med hele $66 \%$. Presentasjonstekstene, der blant annet rapporten inngår, er på $16 \%$ av totalen (Figur 1). 


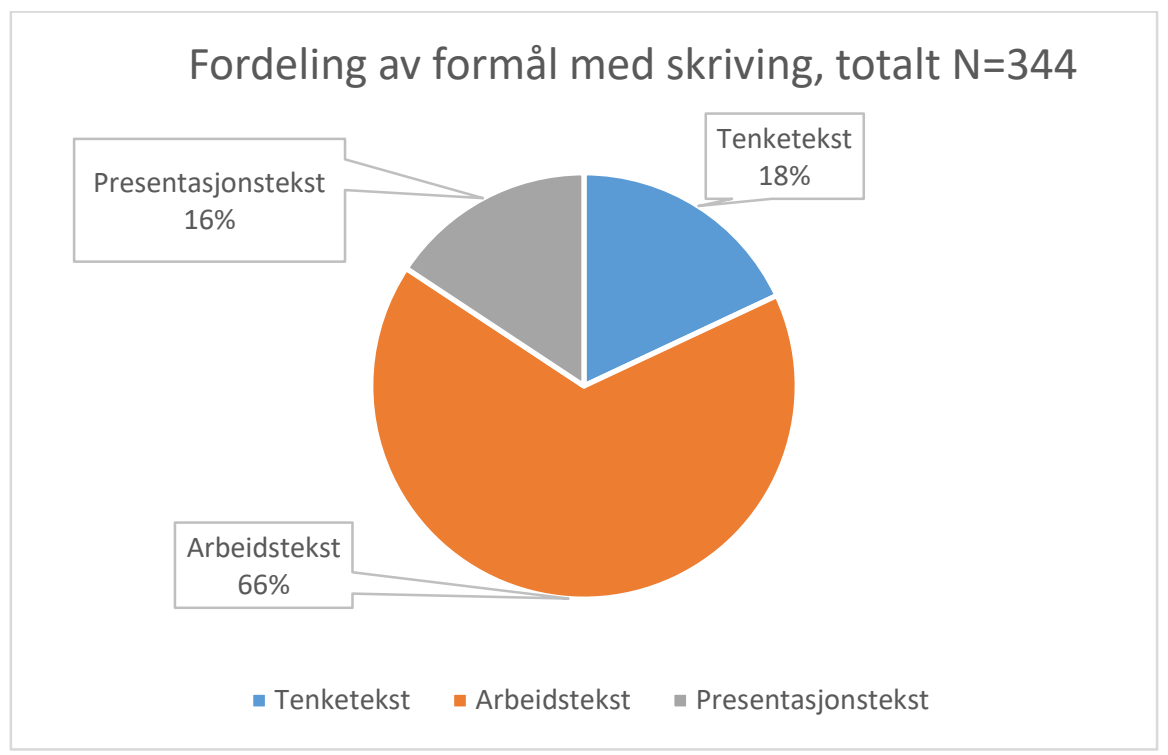

Figur 1 Fordeling av formål med skriving for klasse som jobber med åpen utforsking

I Tabell 3 presenteres innholdet i et utvalg elevtekster som er kodet innen de ulike kategoriene. Da det er 344 tekster i materialet, er kun et utvalg representert, men de viser en bredde i elevtekster som er kategorisert med samme formål.

Tabell 3 Eksempler på elevtekster innen de ulike kategoriene innen formål for skriving i utforskende arbeid

\begin{tabular}{|l|l|}
\hline Kategori & Eksempel på elevtekster \\
\hline Tenketekster & $\begin{array}{l}\text { Tanker om hvilke problemstillinger som er gode å forske på } \\
\text { Logg med tanker om hundeforskning } \\
\text { Tankekart over hvordan man kan forske på hunder } \\
\text { Skisse over fors } \varnothing \text { ksområde til hundefors } \varnothing \mathrm{k}\end{array}$ \\
\hline Arbeidstekster & $\begin{array}{l}\text { Registreringsskjema for hundefors } \varnothing \mathrm{k} \\
\text { Notater fra hundeeksperimenter } \\
\text { Notater fra lesing i bøker og digitale tekster } \\
\text { Søknad til hundeeiere om å låne hund } \\
\text { Oversikt over arbeidsoppgaver under hundefors } \emptyset \mathrm{k} \\
\text { Intervjuguide både til telefonintervju og personlig intervju } \\
\text { Notater under intervju } \\
\text { Kategorisering av resultater som støtter ulike hypoteser }\end{array}$ \\
\hline Presentasjonstekster & $\begin{array}{l}\text { Artikkel om hundens luktesans } \\
\text { Rapporter fra hundefors } \varnothing \mathrm{k} \\
\text { Forside } \\
\text { Innholdsfortegnelse } \\
\text { Forord } \\
\text { Oversikt over vedlegg }\end{array}$ \\
\hline
\end{tabular}


I det følgende framlegger jeg elevtekster som eksempler på alle de tre teksttypene hentet fra kasusen som alle handler om hundeforsøk. Flere av de samme elevene er med på tekstene, fra de første idéene deles, via planlegging og gjennomføring av hundeforsøk til rapporten som ble lagt inn i det endelige bidraget i forskningskonkurransen. Da den største gruppa av elevtekster er arbeidstekster, og mitt bidrag teoretisk gjelder denne kategorien, vil jeg presentere flest eksempler på disse.

\section{Tenketekster}

Tenketekstene som elevene skrev, ble særlig brukt til å få fram ideer eller til å komme videre om de sto fast i prosessen. Tenketeksten under (Figur 2), er et eksempel på å få fram ideer.

Åtte elever hadde påtatt seg oppdraget å tenke på hvordan de kunne gjennomføre eksperimenter med hunder for å teste de ulike hypotesene de hadde. Tord rev løs et ark fra flip-over-en, tok en tusj og begynte å tegne et friområde der de ønsket å gjøre forsøket. Frida skrev på forklaringer, Even og Mari tegnet inn hunder og folk, Kasper og Berit tegnet hvor publikum skulle stå og de to siste pekte og snakket om hvordan de kunne organisere forsøket.

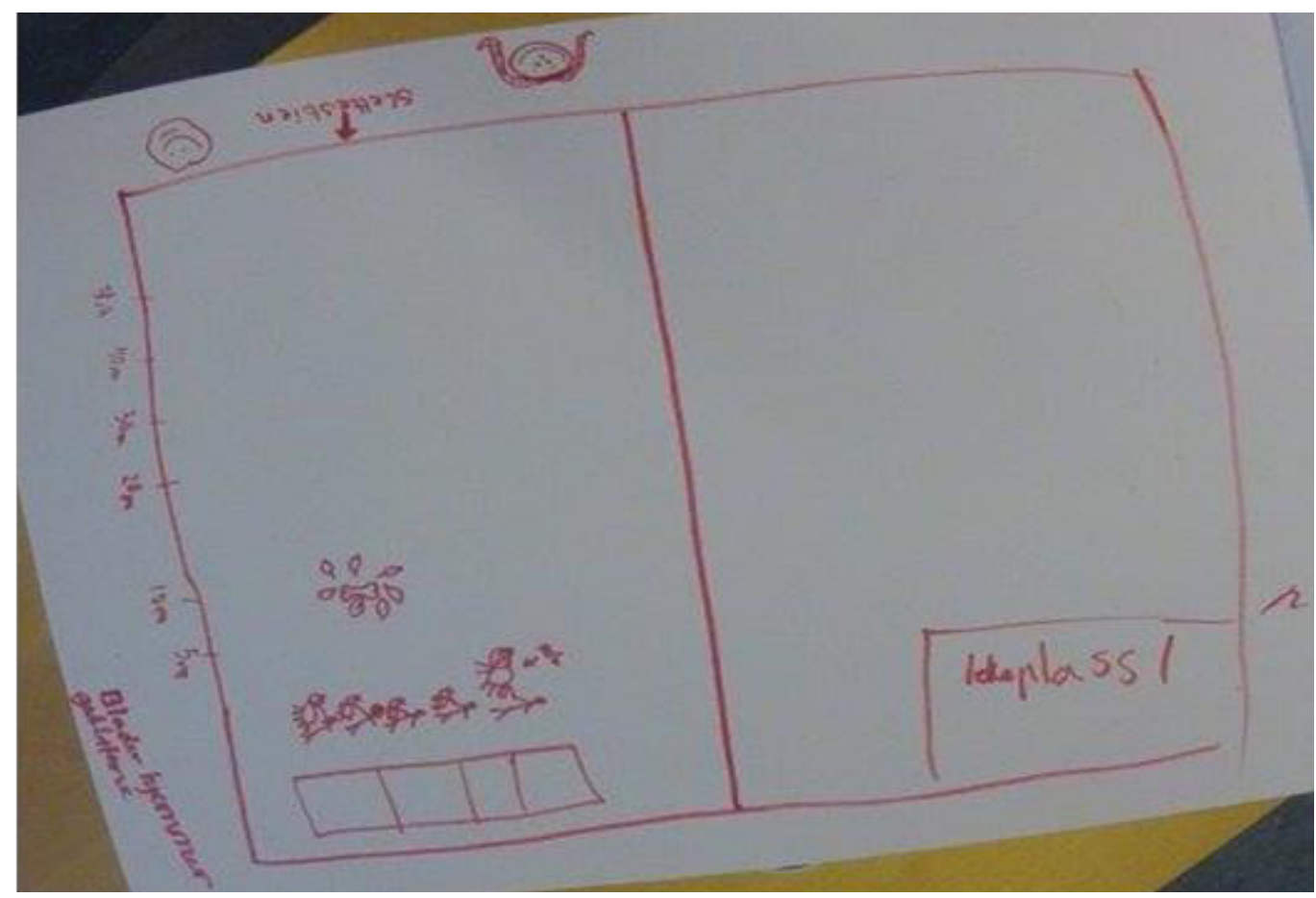

Figur 2 Eksempel på tenketekst, skisse over planer for hundeforsøk

Elevene sier i intervjuet under hva for en tekst de har laget:

Intervjuer: Kan dere forklare hva dere har gjort på dette arket her?

Frida: Ja, her er Slettestien, som er der oppe. Og dette er fotballmål.

Mari: Dette er gress.

Frida: Det er hvordan forsøket kan gjennomføres. Så starter vi her, og gjemmer godbiten her.

Tord: Og da finner vi ut om vi kan slippe dem, om de drar i båndet.

Even: Jeg er nesten sikker på at de stikker ved godbit på 50 meter.

I.: Hvorfor gjorde dere det på denne måten? 
Tord: Vi gjorde det annerledes først.

Kasper: Vi har to til her. (Finner fram to ark til med skisser.)

Frida: Vi gjorde det i fjor, og da var det lurt å tegne. For det viser hvor vi skal være, og hvordan det skal være.

Tenketeksten er en skisse med planer for hvordan hundeforsøk kunne gjennomføres. Den viser et kart over et friområde, oppstilling av hunder med personer, gjemt godbit og indikasjon på avstand målt i meter. Elevene er klare på at det var lurt å tegne for å få idéer, og de viser til to andre skisser de også har laget på dette stadiet.

Andre eksempler på tenketekster i materialet er logg, tankekart og stikkord. Tenketekstene er særlig brukt til å få idéer metodemessig og for analyse av data når informasjonen er krevende å behandle.

\section{Arbeidstekster}

Arbeidstekstene ble særlig skrevet for å planlegge innsamling av data, under innsamlingen og i bearbeidelsen av informasjonen de hadde fått. Her er en situasjon fra hundeforsøksgruppa:

Frida og Tord er i en gruppe med tre andre som skal gjøre et testforsøk med hunden Milla, før hele klassen skal gjøre samme forsøk med fire forskjellige hunder. Hele klassen er samlet på friområdet Slettestien. Frida gjør notater, hun har tatt med en treplate ut, så det skal gå an å skrive utendørs. Tord tar tiden, én elev holder hunden, én markerer ulike metre på bakken og den siste legger ut godbiten. Vil Milla skjønne hva hun skal gjøre? 21 elever ser spent på den ivrige hunden.

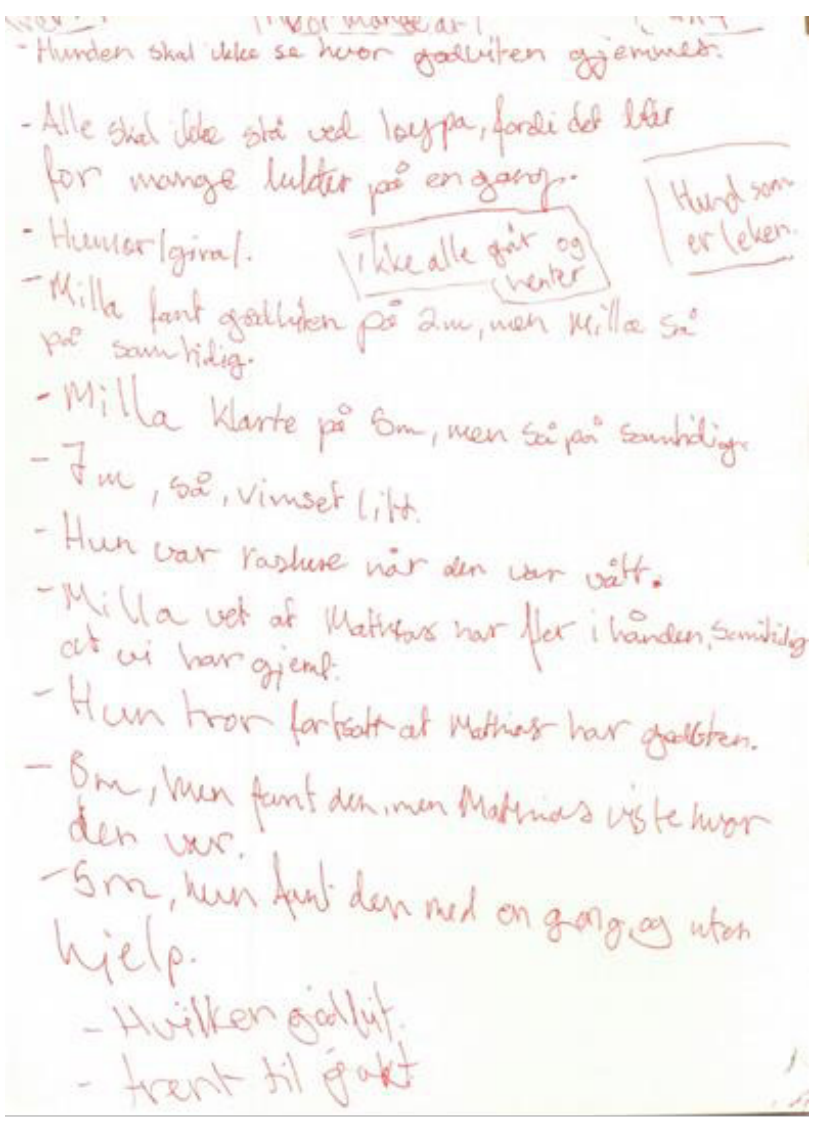

Figur 3 Eksempel på arbeidstekst, notater fra første hundeforsøk 
Gruppa hadde ikke på forhånd avtalt hva Frida skulle skrive, så hun skrev alt hun kom på (Figur 3). Både hvordan hunden oppførte seg, tidspunkt, tanker om forsøket og idéer rundt hypotesene ble skrevet ned. Teksten ble diskutert i forsøksgruppa etterpå. De leste høyt, snakket om hvordan forsøket kunne gjøres bedre. I forlengelsen av dette foreslo Kasper at han kunne filme forsøk med de fire hundene de hadde. Da kunne de samkjøre forsøkene, så det ble enklere å trekke ut informasjon som var mulig å sammenlikne. Figur 4 viser notatene som ble brukt for å finne hvilke klipp som skulle brukes til den endelige filmen om hundeforsøkene.

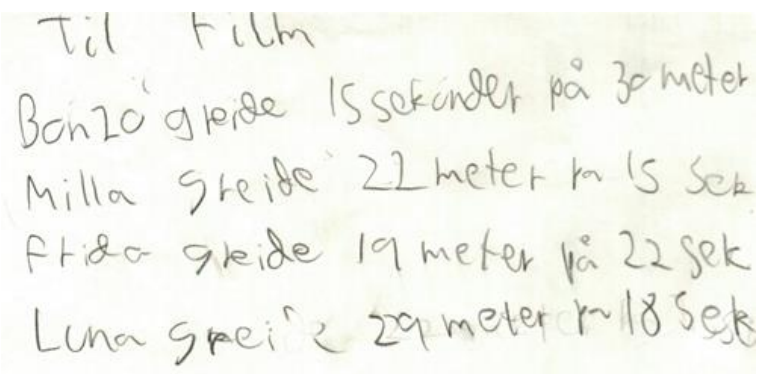

Figur 4 Eksempel på arbeidstekst, notater til hvilke sekvenser som skal brukes iforskningsfilm

En annen viktig metode for å samle informasjon, var å kontakte eksperter som veterinær, ansatte i dyrebutikk og på leirskole eller som under, en i narkotikapolitiet som jobber med hund. Teksten under (Figur 5) viser spørsmål som en elevgruppe forberedte for et telefonintervju med politikvinnen. Dette er skrevet på datamaskin. I tillegg er det håndskrevne notater fra intervjuet som ble foretatt. Arbeidsteksten ble brukt i en påfølgende diskusjon i klassen, blant annet som et innspill arbeidet med å teste hypotesen om alderen på hunden har noe å si for luktesansen.

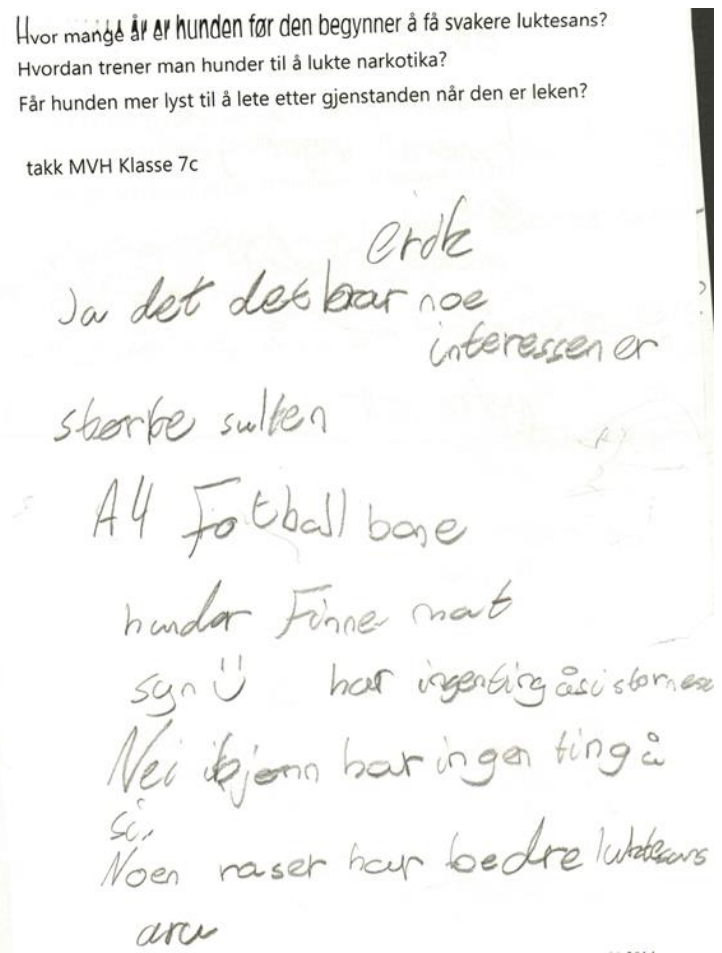

Figur 5 Eksempel på arbeidstekst, notater fra telefonintervju 
I et videostimulert intervju gjort rett etter elevenes telefonintervju der notatene ble gjort, kommer følgende fram:

Intervjuer: Hva er det på dette arket?

Even: Vi skrev fra da vi intervjuet hun i narkotikapolitiet.

Tord: Det er bare svarene, for vi må huske dem.

Even: Ja, og spørsmålene hadde vi, men ikke det hun sa.

I: Hva har dere skrevet?

Even: Det hun sa. Ikke alt, med det viktige. Det er bare så vi husker.

I intervjuet kommer det fram at elevene har skrevet svarene «for vi må huske dem» og poengterer «Det er bare så vi husker.» Dette er derfor en typisk arbeidstekst, den er skrevet i prosessen, for å takle informasjonen de får og er ikke ment for utenforstående.

Den siste arbeidsteksten som presenteres her (Figur 6), ble skrevet mot slutten av forskningsperioden til elevene. De prøvde å samle all informasjon knyttet til de ulike hypotesene de hadde, for å se om datamaterialet de hadde, styrket eller svekket hypotesene. I teksten er hypotesene skrevet med fet og understreket tekst. Noen funn er skrevet på datamaskin, i tillegg har en elevgruppe markert informasjon de har brukt, tegnet på buer og streker som signaler til seg selv.

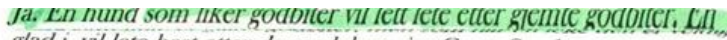

gladi, vil lete best etter denne leken, sier Gusta Sand

En lukt er jo lik om den er luktet før, men hva hunden assosierer med

lukten, vil avgiore hvor stor interesse den viser for den, sier Gro fra

Langedrag.

Noen raser egner seg bedre enn andre og har høyere motivasjon,

jaktlyst etc., sier Gro fra Langedrag.

Hvpotese: De har bedre luktesans hvis de har storre nese. Fordi de som har storre nese får de mer lukt i nesa, og kan derfor lukte lenger.

Vi har funnet ut at ekspertene sier de hundene med stor nese lukter bedre fordi de har plass til flere lukteceller og lukter derfor bedre.
\end{abstract}

Hypotese: Når hunden er ung lukter hunden bedre. Sansene blir svakere når hunden blir gammel.

Forskning har vist at hundens luktesans blir dårligere, men i mye mindre grad enn hos menneskene. Gusta mente at det vil variere fra hund til hund hvor mange år hunden er, før den begynner à fâ svakere luktesans. Hundens luktesans er ofte på sitt beste rundt 5-7 års alderen. Gro mentc at alder har noe å si, hun mente at hundens luktesans på en máte er bedre når den er litt eldre. Siden da har den fâtt mer erfaring og lært mer ả bruke den gode luktesansen sin. (:)

Hypotese: Det er lettere å kjenne lukten igien hvis den har luktet det før.

Vi har fătt mange forskjellige ekspertsvar, så det var vanskelig å si at noe er fakta og noe er usant. En ekspert sa at hunden lukter gjenstanden på

Figur 6 Eksempel på arbeidstekst, notater for å få oversikt over funn koplet til ulike hypoteser 


\section{Tuva Bjørkvold}

Den store mengden arbeidstekster som elevene har skrevet, ble til i de fleste faster av forskningsarbeidet. De trengte arbeidstekster for å finne en god problemstilling, utarbeide presise hypoteser, planlegge metoder for datainnsamling, takle store datamengder, komme i kontakt med eksperter via e-post og brev, ta notater fra både intervjuer samt lesing, og få oversikt over alt materialet de hadde samlet. Tekstene er preget av å være en del av en prosess, med skrivefeil, ufullstendige setninger, uklar struktur, overstrykninger og en salig blanding av modaliteter. Samtidig er det tydelig at tekstene er nødvendige for elevene som jobber utforskende. De trenger å skrive for å takle et kognitivt krevende arbeid, uten gitte framgangsmåter eller svar.

Påfallende er at nesten ingen av disse tekstene er å finne i den endelige rapporten, likevel var de nødvendige for at det ble en rapport i det hele tatt. Tekstene som blir delt med offentligheten, utgjør kun en liten del av arbeidet som blir gjort. Bredden i sjangre og formål for elevene er derfor mye større enn hva rapporten skulle tilsi.

\section{Presentasjonstekster}

Presentasjonstekstene i denne studien ble særlig produsert i to henseende. For det første lagde elevene Visste-du-at-plakater for å vise fram forskningen sin til andre elever ved skolen. For det andre skrev de en rekke presentasjonstekster til den endelige rapporten, både delrapporter, fagartikkel, beskrivelse av gangen i forskningen, metodedel og konklusjon. I tillegg utviklet de tekster som rammet inn rapporten, som forside, forord, innholdsfortegnelse og litteraturliste. Under er en av to rapporter fra forsøk med hunden Milla.

\section{FORSØK MED MILLA:}

Vi har hatt to forskjellige forsøk med Milla: FØRSTE FORSØK:

I det første forsøket var vi på friarealet med Milla. Datoen var 16.1.14.

Vi tok 2 og 2 meter oppover hver gang samtidig som vi tok tiden.

Vi fikk ganske dårlig tid fordi vi hadde glemt godbit så vi måtte tilbake å hente det og fikk derfor litt dårlig tid.

Milla var litt for sterk for han som holdt hunden og derfor mista vi mange forsøk fordi han alltid glapp båndet. Tidtakeren var også litt treig så det ble noen tider som ble feil. Det var veldig mye snø og det var veldig kaldt så det var ganske vanskelig og gjennomføre forsøkene. Vi gjorde det på samme måte hele tiden.

Forsøket gitt ut på at vi skulle gjemme en godbit og se hvor langt unna en hund kunne lukte det. Vi lagde en bane med en pinne for hver andre meter og gikk en pinne framover for hver gang. Hunden sto på samme sted hele tiden og vi gjemte den på forskjellige bredder. På 1 meter klarte hun det på 5 blank.

På 3 meter klarte hun det på 6, 75 sekunder.

På 5 meter brukte hun veldig lang tid fordi hun tråkket på godbiten og brukte derfor veldig lang tid, 17,18 sekunder.

På 7 meter brukte hun 2,55 sekunder men hun så godbiten.

På 9 meter fikk Milla superkrefter og klarte det på 0,33 sekunder. P.S. tidtakeren feila litt og bomma på tiden.

På 11 meter klarte Milla det på 4,66 sekunder.

På 13 meter klarte Milla det på 4,90 sekunder.

På 15 meter klarte Milla det på 17,73 sekunder.

Figur 7 Eksempel på presentasjonstekst, rapport fra hundeforsøk 
I et intervju med utgangspunkt i skrivehendelsen kommer dette fram.

Intervjuer: Hva har dere her? (Peker på teksten.)

Kasper: Det er til forskningsrapporten. Der står det om alt vi vet.

I: Så hva er poenget med den teksten dere har skrevet?

Mari: Den måtte være forståelig. For vi skal gi den ut videre.

I: Hva gjør man for å gjøre den forståelig da?

Kasper: Man tar mellomrom og punktum.

Mari: Vi diskuterte litt. For han mente man ikke skulle ha mellomrom etter komma og punktum og det trodde jeg.

I: Ja. Og på filmen så det ut som dere diskuterte masse om ord og hvordan man staver ord og sånn.

Mari: Fordi det er viktig at det er ordentlig.

Kasper: Vi må ha alt riktig i teksten.

Mari: Ja, det mye viktigere enn i notatene. Fordi denne skal i forskningsrapporten.

Kasper: De notatene skal bare vi lese. Om vi forstår det, så er det ok.

I: Tenker dere litt på hvem som skal lese det.

Mari: Ja. Det er nesten viktigst når vi skriver.

I rapporten har elevene skrevet det de opplevde og observerte underveis. Teksten er skrevet så andre kan forstå den, for en utenforstående mottaker. Dette framheves som «nesten viktigst» av elevene. Den er derfor en typisk presentasjonstekst, skrevet for å presentere materialet for en som ikke kjenner arbeidet til elevene fra før.

\section{DRøFTING}

Problemstillingen i artikkelen var todelt, først: Hvilke formål har tekstene elevene skriver når de jobber utforskende? Med utgangspunkt i en kasusstudie der elever på sjuende trinn gjennomfører et forskningsprosjekt innen en åpen utforsking, er det noen overordnede perspektiver å se på. For det første, etter å ha studert 344 skrivehendelser, trer tydelig skrivepraksiser i denne gruppen fram. Skriving blir brukt aktivt for å takle kompleksiteten i det store forskningsprosjektet til elevene, både for å få gode ideer, gjøre en metodisk tilfredsstillende datainnsamling og ikke minst klare å kople resultatene til hypotesene. Skrivingen blir en nødvendig del av en kultur for kunnskapsutvikling- og forståelse. Elevene skriver mye, på alle stadier i prosessen. Skriving og utforsking, samt formidling framstår som gjensidig avhengig av hverandre, i tråd med det som også kjennetegner vitenskapsfagene i naturfag (Cetina \& Reichman, 2015; Lemke, 1990; Osborne, 2007).

For det andre viser kategoriseringen i tenketekster, arbeidstekster og presentasjonstekster at formålet er ulikt. Elevenes skrivepraksis inkluderer en stor overvekt av arbeidstekster, men også tenketekster i tillegg til presentasjonstekstene som er de eneste som synes i formidlingen. I tillegg til at elevene benytter skriving til ulike formål, viser de også en forståelse for at ulike tekster kan tjene ulike formål. De reflekterer rundt at noen ganger skriver de for å få idéer, andre ganger «for å huske» og atter andre ganger «for å gi den ut videre».

Jeg vil videre drøfte andre del av problemstillingen: Hvilke implikasjoner kan elevenes skrivepraksis ha for utforskende arbeid i skolen? Det er viktig å være oppmerksom på at kasusstudier har sine begrensninger i at utvalget er lite, og i dette tilfellet strategisk valgt, men samtidig kan funnene kaste empirisk lys på teoretiske perspektiver (Yin, 2014). Det er også viktig å være oppmerksom på bekreftelses-bias, at forforståelse rundt hva utforskende arbeidsmetoder innebærer, kan prege hvordan resultatene drøftes i lys av liknende situasjoner (Nicerson, 1998). Jeg mener derfor at termene som anvendes til å beskrive skriveformålene i denne kasusstudien kan ha relevans utover denne konteksten. 
Termene tenketekster og presentasjonstekster har vært brukt innen skriving siden Hoel skrev om disse på studentnivå i 1997. Med min innføring av termen arbeidstekster făr skriveprosessen en ny dimensjon som kan være nyttig både i forskning og praktisk arbeid i skolen. Den store grad av frihet og sakskompleksitet i den åpne utforskingen i dette prosjektet har bidratt til at elevene har kunnet utvikle sin egen praksis. Denne praksisen er preget av høyt ambisjonsnivå for elevene, noe som tydeliggjøres i den store andelen arbeidstekster. I andre varianter av utforskende arbeid, for eksempel lærerstyrt utforsking (Knain og Kolstø, 2011), kan likevel arbeidstekster være sentrale å jobbe med, fordi en vektlegging av disse framhever viktigheten av at elevene selv konstruerer sin egen kunnskap. Det er tre poeng jeg mener kan være nyttige å ta med seg til skolen, på alle trinn.

For det første: Om elever skal få oppleve også den fundamentale forståelsen av naturfaget i skolen, må de få arbeide med prosesser som i større grad tilsvarer det forskerne driver med (Howes et al., 2009; Norris \& Phillips, 2003; Osborne, 2007). Forskere skriver mye på vei til å kunne publisere, uansett fagområde i naturfag (Knain, 2015). Om elevene får jobbet med arbeidstekster, og får en forståelse av at disse tekstene er nødvendige for å kunne nå et endelig produkt i presentasjonstekstene, vil de også få et mer realistisk bilde av hvordan forskere jobber, og ikke minst hvordan kunnskap konstrueres (Lemke, 1990). Arbeidstekstene gir legitimitet for at det kreves mye skriving på veien til en klar forståelse.

For det andre kan termen arbeidstekster senke terskelen for å skrive. For elever som jobber utforskende, kan veien fram til en ferdig rapport eller fagartikkel virke uoverkommelig. Om termen arbeidstekster blir introdusert som et steg på veien, der ikke sjangerkrav, rettskriving eller gode formuleringer er et tema, men hensikten er å få oversikt, kan elevene enklere jobbe med bare dette. Elevene får dermed frigjort kognitiv kapasitet til å arbeide med å forstå prosessen de er i, vektlegge utforskingen, og ikke det endelige produktet. De trenger heller ikke å vende seg mot en ukjent mottaker, men konsentrere seg om å få orden på data de har så langt, hvordan de skal planlegge neste steg, eller å ta notater til bruk for egen eller gruppas del.

For det tredje kan det å innføre arbeidstekster være et godt grep for å unngå avskrift. Om en ikke har god nok forståelse av innhold, vil de aller fleste ty til avskrift, eller i beste fall parafrasering (Blåsjö, 2010). Ved å vente med å introdusere hva det ferdige produktet skal være, for eksempel en rapport eller en fagartikkel, vil elevene gjennom arbeidstekster kunne bruke tid på å tilegne seg innholdet de trenger. Senere, når innholdet i stor grad er på plass, kan elevene jobbe med sjangerkonvensjoner for de ulik typer av tekst de skal produsere.

I forsking på utforskende arbeidsmåter kan en kategorisering av elevtekstene i tenketekster, arbeidstekster og presentasjonstekster si noe om i hvor stor grad elevene konstruerer sin egen kunnskap, eller gjenskaper skolens tekster (Säljö, 2013). Om elevene kun skriver presentasjonstekster, har de trolig ikke balet med uhåndterlig data og kommet dypere inn i fagfeltet (Graham og Perin, 2007). Kun presentasjonstekster vil trolig gjenspeile en reproduserende skrivepraksis, som vi vet er utbredt i skolen (Sørvik og Mork, 2015). En større mengde arbeidstekster i elevenes skriving kan tyde på at de har stått i prosessen, og dermed nærmet seg den fundamentale forståelsen av naturfaget (Norris \& Phillips, 2003). Arbeidstekster vil også kunne tyde på at elevene har vært i kontakt med andre i arbeidet, gjennom for eksempel brev, e-poster, spørreundersøkelser og intervju. Den sosiale siden ved naturfaglig kunnskapskonstruksjon, blir dermed også tydeliggjort (Klein \& Boscolo, 2016; Sørvik, Blikstad-Balas \& Ødegaard, 2015).

Et siste poeng å ta med seg videre i skolen er hvordan arbeidstekster kan inngå som en del av vurderingen i skolen. Arbeidstekster er, som termen sier, tekster i prosess, og egner seg derfor godt å anvende i den formative vurderingen, for å vurdere hvor eleven er på vei, og hvilke tanker han eller hun gjør seg om sin egen kunnskapsutvikling (Hattie \& Timperley, 2007). Men også i den summative vurderingen kan arbeidstekster spille en rolle, om prosessen i utforskende arbeid skal vurderes. Arbeidstekster kan da egne seg til å vise nettopp veien mot et produkt, og inngå som dokumentasjon på utforskingskompetanse. 
En del av de mulige implikasjonene som er drøftet ovenfor ville kunne bli styrket i videre praksis i skolen og forskning. Om de tre kategoriene av formål, tenketekster, arbeidstekster og presentasjonstekster, hadde blitt prøvd ut i praksis i ulike skoleslag, kunne en sett funksjonaliteten av begrepene også i andre elevgrupper. En kunne forsket på om en økt bevissthet om teksters ulike formål, og arbeidstekster spesielt, vil gi elever større forståelse av den utforskende arbeidsprosessen, og om også andre elever enklere ville benytte seg av arbeidstekster i utforskende arbeid. Dette kunne være interessant videre forskning.

\section{KONKLUSJON}

Elever som jobber med utforskende arbeidsmåter vil ofte være avhengige av tekst for å planlegge arbeidet, samle og håndtere data samt presentere funnene sine. Dette samsvarer med hvordan voksne forskere arbeider, tekst og forsking er gjensidig avhengig av hverandre (Lemke, 1990). Ved å framheve termen arbeidstekster kan både lærere og elever få en større forståelse og trygghet for at det krever mye skriving for å få fram klare tanker som kan presenteres. Arbeidstekster gir rom for refleksjon og kritisk tenking i en krevende utforskende arbeidsprosess. Videre kan de gi en forståelse for vitenskapelig og hvordan kunnskap konstrueres. Når så stoffet, gjennom arbeidstekster, er blitt elevenes eget, kan de gi seg i kast med presentasjonstekstene.

\section{LITTERATUR}

Abd-El-Khalick, F., Boujaoude, S., Duschl, R., Lederman, N. G., Mamlok-Naaman, R., Hofstein, A., . .. Tuan, H.-1. (2004). Inquiry in science education: International perspectives. Science Education, 88(3), 397-419. doi:10.1002/sce.10118

Barton, D. (2007). Literacy: An introduction to the ecology of written language. Malden, Mass.: Blackwell Publisher.

Barton, D., \& Hamilton, M. (2000). Literacy practices. I D. Barton, M. Hamilton, \& R. Ivanič (Eds.), Situated literacies: Reading and writing in context (s. 7-15). London: Routledge.

Bjørkvold, T. (2013). Autentisk skriving i og utenfor klasserommet. Nysgjerrigper-metoden som eksempel. I Skjelbred. D. og Veum, A. (red.) Literacy i læringskontekster. Oslo: Cappelen Damm Akademisk. (s. 178-188).

Bjørkvold, T. og Blikstad-Balas, M. (2017). Students as researchers - What and why $7^{\text {th }}$ grade students choose to write when investigating their own research question. Science Education, 2017:1-38, doi 10.1002/sce.21324

Blikstad-Balas, M. (2016). Key challenges of using video when investigating social practices in education: C-ontextualization, magnification, and representation. International Journal of Research \& Method in Education, 40(5), 511-523.

Blåsjö, M. (2010). Appropriering av fackkunskap förutsättning för ett «godkänt» akademiskt skrivande. I G. Å. Vatn, I. Folkvord, \& J. Smidt (Eds.), Skriving i kunnskapssamfunnet (s. 143159). Trondheim: Tapir akademisk forlag.

Cervetti, G. N., Barber, J., Dorph, R., Pearson, P. D., \& Goldschmidt, P. G. (2012). The impact of an integrated approach to science and literacy in elementary school classrooms. Journal of Research in Science Teaching, 49(5), 631-658. doi:10.1002/tea.21015

Cetina, K. K., \& Reichmann, W. (2015). Epistemic Cultures. I International encyclopedia of the social \& behavioral sciences. (s. 873-880) Elsevier Ltd.

Cohen, L., Bell, R. C., Manion, L., \& Morrison, K. (2011). Research methods in education (7 ed.). London: Routledge.

Creswell, J. W. (1998). Qualitative inquiry and research design: Choosing among five traditions. Thousand Oaks, Calif: Sage.

Creswell, J. W. \& Miller, D. L. (2010). Determining validity in qualitative inquiry. Theory Into Practice, 39(3), 124-130. 
Danielsson, K. (2010). Learning chemistry: Text use and text talk in a Finland-Swedich chemistry classroom. IARTEM e-journal, 3(2), 1-28.

Danielsson, K. (2013). Multimodal literacy i klassrummet: Möjligheter och begränsningar. I D. Skjelbred \& A. Veum (Eds.), Literacy i læringskontekster (s. 120-136). Oslo: Cappelen Damm Akademisk.

Flyvbjerg, B. (2010). Fem misforståelser om casestudiet. I S. Brinkmann, \& L. Tanggaard (Red.), Kvalitative metoder: En grundbog (s. 463-487). København: Reitzel.

Furøy, K. A., Møllhausen, M., \& Hauge, T. (2014). Nysgjerrigpermetoden: Vitenskapelig metode til skolebruk: Lærerveiledning. Oslo: Norges Forskningsråd, Nysgjerrigper.

Gall, M. D., Gall, J. P. \& Borg, W. R. (2007). Educational research: An introduction (8th ed. utg.). Boston, Mass.: Allyn and Bacon.

Gee, J. P. (2015a). Literacy and education. New York: Routledge.

Gee, J. P. (2015b). Social linguistics and literacies: Ideology in discourses (5 utg.). London: Routledge.

Graham, S., \& Perin, D. (2007). Writing next: Effective strategies to improve writing of adolescents in middle and high schools. A report to Carnegie Corporation of New York. In. New York Alliance for excellent education.

Hammersley, M. (2008). Troubles with triangulation. I M. M. Bergman (Red.), Advances in Mixed Methods Research (s. 22-36): SAGE.

Hattie, J. , \& Timperley, H. (2007). The power of feedback. Review of Educational Research , 77, 81-112.10.3102/003465430298487

Hezig, A.-W. (2011). The publish or perish book: Part 1 a guide to the software. Melbourne: Tama software research

Herron, M. D. (1971). The nature of scientific inquiry. The School Review, 79(2), 171-212.

Hoel, T. L. (1997). Innoverretta og utoverretta skriveforsking og skriveteoriar. I L. S. Evensen \& T. L. Hoel (Eds.), Skriveteorier og skolepraksis (s. 3-44). Oslo: Landslaget for norskundervisning: Cappelen akademisk.

Howes, E. V., Lim, M., \& Campos, J. (2009). Journeys into inquiry-based elementary science: Literacy practices, questioning, and empirical study. Science Education, 93(2), 189-217. doi:10.1002/sce.20297

Klein, P. D., \& Boscolo, P. (2016). Trends in research on writing as a learning activity. Journal of Writing Research, 7(3), 311-350. doi:10.17239/jowr-2016.07.03.01

Knain, E. (2015). Scientific literacy for participation: A systemic functional approach to analysis of school science discourses. Rotterdam: Sense Publishers.

Kolstø, S. D., \& Knain, E. (2011). Elever som forskere i naturfag. Oslo: Universitetsforlaget.

Kunnskapsdepartementet. (2013). Læreplanverket for Kunnskapsløftet. Utdanningsdirektoratet. Hentet fra https://sokeresultat.udir.no/finn-lareplan.html 16.01.2018

Kunnskapsdepartementet. (2017). Overordnet del: Verdier og prinsipper for grunnopplæringen. Hentet fra https://www.regjeringen.no/contentassets/37f2f7e1850046aoa3f676fd45851384/ overordnet-del---verdier-og-prinsipper-for-grunnopplaringen.pdf 12.04.2019

Kvale, S., \& Brinkmann, S. (2009). Interviews: Learning the craft of qualitative research interviewing. Los Angeles, Calif.: Sage.

Lemke, J. L. (1990). Talking science: Language, learning, and values. Norwood, N. J.: Ablex.

Lyons, T. (2006). Different countries, same science classes: Students' experiences of school science in their own words. International Journal of Science Education, 28(6), 591-613.

Mills, H., O'Keefe, T., Hass, C. \& Johnson, S. (2014). Changing hearts, minds, and actions through collaborative inquiry. Language Arts, 92(1), 36-51.

Nickerson, R. S. (1998). Confirmation bias: A ubiquitous phenomenon in many guises. Review of General Psychology, 2(2), 175-220.

Norris, S. P., \& Phillips, L. M. (2003). How literacy in its fundamental sense is central to scientific literacy. Science Education, 87(2), 224-240. doi:10.1002/sce.10066

Nysgjerrigper. (2018). Deltakelse i Årest Nysgjerrigper. Norges Forskningsråd. 
Osborne, J. (2007). Science education for the twenty first century. Eurasia Journal of Mathematics, Science \& Technology Education, 3(3), 173-184.

Rish, R. M. (2015). Researching writing events: Using mediated discourse analysis to explore how students write together. Literacy, 49(1), 12-19. doi:10.1111/lit.12052

Stake, R. E. (2005). Qualitative case studies. I N. K. Denzin, \& Y. S. Lincoln (Red.), The SAGE handbook of qualitative research (s. 443-466). Thousand Oaks, Calif.: SAGE.

Street, B., \& Hornberger, N. (2008). Literacy. New York: Springer.

Säljö, R. (2013). Literacy och lärande: Inskriptioner och kunskapsutveckling. I L. Östman, E. Lundqvist, \& R. Säljö (Eds.), Scientific literacy: Teori och praktik (s. 19-40). Malmø: Gleerups.

Sørvik, G. O., Blikstad-Balas, M., \& Ødegaard, M. (2015). “Do books like these have authors?” New roles for text and new demands on students in integrated science-literacy instruction. Science Education, 99(1), 39-69. doi:10.1002/sce.21143

Sørvik, G. O., \& Mork, S. M. (2015). Scientific literacy as social practice: Implications for reading and writing in science classrooms. NorDiNa, 11(3), 268-281.

Yin, R. K. (2014). Case study research: Design and methods. Los Angeles, Calif.: SAGE.

Yore, L., D., Hand, B., Goldman, S. R., Hildebrand, G. M., Osborne, J. F., Treagust, D. F., \& Wallace, C. S. (2004). New directions in language and science education research. Reading Research Quarterly, 39(3), 347-352.

Ødegaard, M., Haug, B., Mork, S. M., \& Sørvik, G. O. (2014). Challenges and support when teaching science through an integrated inquiry and literacy approach. International Journal of Science Education, 36(18), 2997-3020. doi:10.1080/09500693.2014.942719 